\title{
Impact of temperature on the biological properties of soil
}

\author{
Agata Borowik and Jadwiga Wyszkowska* \\ Department of Microbiology, University of Warmia and Mazury in Olsztyn, Plac Łódzki 3, 10-727 Olsztyn, Poland \\ Received May 12, 2015; accepted December 7, 2015
}

\begin{abstract}
A b s t r a c t. The aim of the study was to determine the response of soil microorganisms and enzymes to the temperature of soil. The effect of the temperatures: $5,10,15,20$, and $25^{\circ} \mathrm{C}$ on the biological properties of soil was investigated under laboratory conditions. The study was performed using four different soils differing in their granulometric composition. It was found that $15^{\circ} \mathrm{C}$ was the optimal temperature for the development of microorganisms in soil. Typically, in the soil, the highest activity of dehydrogenases was observed at $10-15^{\circ} \mathrm{C}$, catalase and acid phosphatase - at $15^{\circ} \mathrm{C}$, alkaline phosphatase at $20^{\circ} \mathrm{C}$, urease and $\beta$-glucosidase at $25^{\circ} \mathrm{C}$. The highest colony development index for heterotrophic bacteria was recorded in soils incubated at $25^{\circ} \mathrm{C}$, while for actinomycetes and fungi at $15^{\circ} \mathrm{C}$. The incubation temperature of soil only slightly changed the ecophysiological variety of the investigated groups of microorganisms. Therefore, the observed climate changes might have a limited impact on the soil microbiological activity, because of the high ability of microorganisms to adopt. The response of soil microorganisms and enzymes was more dependent on the soil granulometric composition, organic carbon, and total nitrogen than on its temperature.

K e y w o r d s: soil temperature, microorganisms, ecophysiological biodiversity, enzyme acivity
\end{abstract}

\section{INTRODUCTION}

One of the most important factors determining microbial and biochemical soil activity is temperature. The soil temperature depends on the climate zone, physicochemical properties, and natural topography (Singh et al., 2010; Adak and Chakravarty, 2013; Kodaira, 2014). Adak and Chakravarty (2013) demonstrated a strong correlation of soil temperature with air temperature. They indicated a correlation between the surface temperature of the soil and its biological and physical properties.

\footnotetext{
*Corresponding author e-mail: jadwiga.wyszkowska@uwm.edu.pl
}

The amplitude of temperature fluctuations in a soil profile changes periodically, or daily, weekly, monthly, seasonally, and annually. These changes are a function of the climate zone and the depth of a soil profile. This is confirmed by the studies of Licznar and Rojek (2004), according to which, in most Polish soils, the disappearance of daily temperature fluctuations occurs at a depth of 50-60 cm. Michalska and Nidzgorska-Lencewicz (2010) suggested that in a light loam profile, in the area of the Gumieniecka Plain near Szczecin 53 $26^{\prime} 17^{\prime \prime} \mathrm{N} 14^{\circ} 32^{\prime} 32^{\prime \prime} \mathrm{E}$, the highest average annual temperature reaches $11.6^{\circ} \mathrm{C}$ and the lowest $7.8^{\circ} \mathrm{C}$. This temperature is suitable for psychrophilic microorganisms present in soil. The authors report that the soil temperature is variable at all levels of the soil profile, with the greatest variations relating to the spring period. Licznar and Rojek (2004) have shown that the soil temperature also depends on the moisture content. The temperature amplitudes observed in desiccated soils were larger in comparison to moist soils.

Temperature is one of the main factors that determine the activity of soil microorganisms (Järvan et al., 2014). Microorganisms are involved in numerous processes controlling the flow of nutrients through specific enzymes located inside the cell (Borowik et al., 2014; Jastrzębska and Kucharski, 2007; Wyszkowska et al., 2013), and their activity is dependent, among others, on the temperature. Järvan et al. (2014) suggest that temperature is one of the most important factors influencing the count and occurrence of microorganisms and is also a determinant of the activity of intracellular and extracellular enzymes. The temperature of the soil affects the stability and resistance

(C) 2016 Institute of Agrophysics, Polish Academy of Sciences 
of microorganisms (D'Amico et al., 2006) as well as their activity, regardless of their feeding type. It is a factor that limits the activity of both heterotrophic and litotrophic microorganisms (Zeppel et al., 2012).

It is widely assumed that soil microorganisms are mesophilic microorganisms. However, this view may be not valid in all climate zones. In the case of Polish soils, it should rather be recognized that the most active are psychrophilic microorganisms, although the important role of mesophilic microorganisms, whose survival varies over a fairly wide range of temperatures, cannot be excluded. According to Tortora et al. (2004), the optimum temperature for growth of psychrophilic bacteria is between 15 to $20^{\circ} \mathrm{C}$ and for mesophilic bacteria from 20 to $40^{\circ} \mathrm{C}$. With the above-mentioned data in mind, it is extremely important to determine a correlation between the soil temperature and microbial activity. Therefore, the aim of this study was to determine the relationship between soil temperature and the growth and development of microorganisms, their diversity, and activity of soil enzymes.

\section{MATERIALS AND METHODS}

In the laboratory experiment, the soil material collected from the arable humus level of typical brown earths (Eutric Cambisol) originated from the Experimental Teaching Centre in Tomaszkowo (north-eastern Poland, $53.7167^{\circ} \mathrm{N}$, $20.4167^{\circ} \mathrm{E}$ ). According to the classification of grain size by the United States Department of Agriculture, the soil was characterized by the following granulometric composition: sand (S), loamy sand (LS), sandy loam (SL), and silty loam
(SiL). The properties of the soil are shown in Table 1. The soils used in the experiment were passed through a sieve with a mesh size of $2 \mathrm{~mm}$.

The study was conducted under laboratory conditions. The soils (S, LS, SL, or SiL) in an amount of $100 \mathrm{~g} \mathrm{d.m.}$ were placed in glass beakers with a capacity of $150 \mathrm{~cm}^{3}$. Soil moisture content was adjusted to $60 \%$ of capillary water capacity using sterile distilled water. The beakers were covered with perforated foil, and the soil was incubated for 16 weeks in incubators at $5,10,15,20$, or $25^{\circ} \mathrm{C}$. In the 4 th and 16 th week, the experiment was partially liquidated and microbiological and biochemical properties were determined in the samples of the soils mixed in the beakers. Water loss was supplemented once a week. The experiment was conducted in 3 replicates for each period. The total number of beakers for each soil was 30 .

The count of soil microorganisms in the individual soil samples collected from each beaker was determined using a plate count method in 5 replicates. The count of heterotrophic bacteria, colonies of Azotobacter, actinomycetes, and fungi was determined on the media characterized by Kucharski and Wyszkowska (2004). Microorganisms were cultured at $28^{\circ} \mathrm{C}$. The grown colonies of the Azotobacter were counted after 2 days, those of heterotrophic bacteria and actinomycetes after 7 days, and those of fungi after 5 days. In order to determine the colony development index (CD) of microorganisms and their ecophysiological diversity index (EP), the cultures of appropriate solutions with a medium were counted daily for 10 consecutive days. The colony development index $\mathrm{CD}=\left[\mathrm{N}_{1} / 1+\mathrm{N}_{2} / 2+\mathrm{N}_{3} / 3 \ldots \ldots\right.$

T a b l e 1. Physicochemical properties of the soil

\begin{tabular}{|c|c|c|c|c|c|}
\hline \multirow{2}{*}{\multicolumn{2}{|c|}{ Soil properties }} & \multicolumn{4}{|c|}{ Soil type } \\
\hline & & \multirow{2}{*}{$\begin{array}{c}\text { Sand } \\
92.47\end{array}$} & \multirow{2}{*}{$\begin{array}{c}\text { Loamy sand } \\
85.18\end{array}$} & \multirow{2}{*}{$\begin{array}{c}\text { Sandy loam } \\
51.27\end{array}$} & \multirow{2}{*}{$\begin{array}{c}\text { Silty loam } \\
34.96\end{array}$} \\
\hline \multirow{3}{*}{$\begin{array}{l}\text { Percentage } \\
\text { of fraction (d) }\end{array}$} & $2.00 \geq \mathrm{d}>0.05 \mathrm{~mm}$ & & & & \\
\hline & $0.05 \geq \mathrm{d}>0.002 \mathrm{~mm}$ & 7.07 & 13.82 & 45.36 & 60.21 \\
\hline & $\mathrm{d} \leq 0.002 \mathrm{~mm}$ & 0.46 & 1.00 & 3.37 & 4.83 \\
\hline $\mathrm{pH}_{\mathrm{KCl}}$ & & 6.6 & 6.3 & 6.8 & 7.0 \\
\hline HAC & & 6.5 & 14.4 & 5.2 & 6.5 \\
\hline EBC & \multirow{2}{*}{$\mathrm{mM}(+) \mathrm{kg}^{-1}$ of soil d.m. } & 35.5 & 49.2 & 131.4 & 197.2 \\
\hline CEC & & 42.0 & 63.6 & 136.6 & 203.7 \\
\hline BS & $\%$ & 84.5 & 77.3 & 96.2 & 96.8 \\
\hline $\mathrm{C}_{\text {org }}$ & \multirow{2}{*}{$\mathrm{g} \mathrm{kg}^{-1}$ of soil d.m. } & 3.9 & 6.7 & 9.9 & 9.9 \\
\hline $\mathrm{N}_{\mathrm{c}}$ & & 0.03 & 0.61 & 1.14 & 1.38 \\
\hline $\mathrm{K}_{\mathrm{w}}$ & \multirow{4}{*}{$\mathrm{mg} \mathrm{kg}^{-1}$ of soil d.m. } & 66 & 168 & 168 & 196 \\
\hline $\mathrm{Na}_{\mathrm{w}}$ & & 41 & 46 & 57 & 53 \\
\hline $\mathrm{Ca}_{\mathrm{w}}$ & & 599 & 812 & 2214 & 3556 \\
\hline $\mathrm{Mg}_{\mathrm{w}}$ & & 26 & 28 & 50 & 74 \\
\hline
\end{tabular}

HAC - hydrolytic acidity, EBC - sum of exchangeable cations, CEC - cation exchange capacity, BS - base saturation; $\mathrm{C}_{\text {org }}$ - organic carbon, $\mathrm{c}$ - total, $\mathrm{w}$ - replaceable. 
$\left.\mathrm{N}_{10} / 10\right]$ 100, where $\mathrm{N}_{1}, \mathrm{~N}_{2}, \mathrm{~N}_{3}, \ldots . \mathrm{N}_{10}$ is a proportional count of colonies grown in (Sarathchandra et al., 1997), and the ecophysiological diversity index $\mathrm{EP}=-\sum$ (pi log pi), where pi is the number of microbial colonies from a given day divided by the total number of colonies (De Leij et al., 1993), were then calculated.

Enzyme activity, similarly to the microbial count, was determined in the individual soil samples. The measurements were performed in each sample in 3 replicates. Dehydrogenase activity (EC 1.1) was determined using the Lenhard method modified by Öhlinger (1996), while catalase (EC 1.11.1.6), urease (EC 3.5.1.5), arylsulfatase (EC 3.1.6.1), $\beta$-glucosidase (EC 3.2.1.21), acid photsphatase (EC 3.1.3.2), and alkaline phosphatase activities (EC 3.1.3.1) were determined according to Alef et al. (1998).

The following substrates for the enzymes were used: 2,3,5-triphenyltetrazolium chloride (TTC) for dehydrogenases, hydrogen peroxide for catalase, disodium 4-nitrophenylphosphate (PNPNa) for phosphatases, urea for urease, p-nitrophenyl- $\beta$-D-glucopyranoside (PNG) for $\beta$-glucosidase, and potassium 4-nitrophenylsulfate (PNS) for arylsulfatase. Enzyme activity was expressed per $1 \mathrm{~kg}$ of soil d.m. $\mathrm{h}^{-1}$ in the following units: $\mu \mathrm{M}$ of triphenylformazan (TPF) for dehydrogenases, $\mathrm{M}_{\text {of }} \mathrm{O}_{2}$ for catalase, $\mathrm{mM}$ of $\mathrm{N}^{-\mathrm{NH}_{4}}$ for urease, and $\mathrm{mM}$ of p-nitrophenol (PNP) for acid phosphatase, alkaline phosphatase, $\beta$-glucosidase, and arylsulfatase. All enzyme activity assays, except for catalase, were performed using a Perkin-Elmer Lambda 25 (Massahusets, USA) spectrophotometer.

Prior to the experiment, the granulometric composition of the soil samples was determined using a laser particle size analyser Mastersizer 2000; their $\mathrm{pH}$ was determined by a potentiometric method in an aqueous solution of $\mathrm{KCl}$ at a concentration of $1 \mathrm{M} \mathrm{dm}^{3}$; hydrolytic acidity (HAC) and sum of exchangeable cations (EBC) - by the Kappen method (Carter, 1993), content of total nitrogen according to the method by Kjeldahl, and the content of bioavailable phosphorus, potassium, calcium, and magnesium accord- ing to the Atomic Absorption Spectrometry (ASA) method; organic carbon $\left(\mathrm{C}_{\text {org }}\right)$ content - by the Tiurin method (Nelson and Sommers, 1996). Based on the HAC and EBC values, cation exchange capacity (CEC) and the degree of soil saturation with basic elements (BS) were calculated. The following formulas were used: $\mathrm{CEC}=\mathrm{EBC}+\mathrm{HAC}$; $\mathrm{BS}=$ (EBC/CEC) 100.

The analysis of ANOVA variance for the results was performed using the Statistica 10.0 (StatSoft, 2012) package. Homogenous groups were calculated with Tukey test, at $p=0.01$. Simple Pearson correlation coefficients were calculated for dependent and independent variables. The results were also analyzed using the PCA test (principal component analysis). Moreover, analysis of variance ANOVA was used to calculate the $\eta^{2}$ coefficient, which specifies the contribution of each independent variable to the formation of dependent variables.

In this study, the results of biological and biochemical analyses were presented as the means from two periods, because the analysis of $\eta^{2}$ coefficients showed that the soil incubation time did not significantly affect the count of microorganisms, their diversity, and enzyme activity.

\section{RESULTS}

The studies demonstrate that the temperature, regardless of the type of soil formation, significantly shapes the conditions for growth and development of microorganisms (Table 2). Heterotrophic bacteria, Azotobacter, actinomycetes, and fungi proliferated the most intensively in the soils incubated at $15^{\circ} \mathrm{C}$. At this temperature, their count was from $29 \%$ (actinomycetes) to $67 \%$ (Azotobacter) higher in comparison to the soils at $5{ }^{\circ} \mathrm{C}$, and from $23 \%$ (fungi) to $42 \%$ (heterotrophic bacteria) higher in comparison to the soils incubated at $25^{\circ} \mathrm{C}$.

The PCA analysis clearly indicates that the best temperature for soil microorganisms is $15^{\circ} \mathrm{C}$, while the least favourable temperatures are 5 and $25^{\circ} \mathrm{C}$ (Fig. 1). The microbiological properties of individual soil formations differed

T a b l e 2. Impact of temperature on the count of soil microorganisms

\begin{tabular}{|c|c|c|c|c|}
\hline \multirow{3}{*}{$\begin{array}{l}\text { Temperature } \\
\left({ }^{\circ} \mathrm{C}\right)\end{array}$} & \multicolumn{4}{|c|}{ Microorganisms } \\
\hline & Org $\times 10^{9}$ & $\mathrm{Az} \times 10^{3}$ & Act $\times 10^{9}$ & Fun $\times 10^{7}$ \\
\hline & \multicolumn{4}{|c|}{$10^{\mathrm{n}}$ cfu kg-1 soil d.m. } \\
\hline 5 & $15.14 \mathrm{c}$ & $6.50 \mathrm{c}$ & $7.55 \mathrm{c}$ & $32.16 \mathrm{~d}$ \\
\hline 10 & $18.68 \mathrm{~b}$ & $8.29 b$ & $8.57 \mathrm{~b}$ & $39.50 \mathrm{~b}$ \\
\hline 15 & $20.61 \mathrm{a}$ & $10.84 \mathrm{a}$ & $9.67 \mathrm{a}$ & $42.99 \mathrm{a}$ \\
\hline 20 & $14.71 \mathrm{c}$ & $9.28 \mathrm{ab}$ & $7.50 \mathrm{c}$ & $36.71 \mathrm{c}$ \\
\hline \multirow[t]{3}{*}{25} & $12.25 \mathrm{~d}$ & $8.14 b$ & $5.56 \mathrm{~d}$ & $32.96 \mathrm{~d}$ \\
\hline & \multicolumn{4}{|c|}{ Coefficient of correlation } \\
\hline & -0.46 & 0.42 & $-0.53^{*}$ & -0.04 \\
\hline
\end{tabular}

Org - organotrophic bacteria, Az - Azotobacter, Act - actinomycetes, Fun - fungi; the same letters in the columns indicate homogeneous groups; *correlation significant at $\mathrm{p} \leq 0.01$ between temperature and count of microorganisms $\mathrm{n}=23$. 


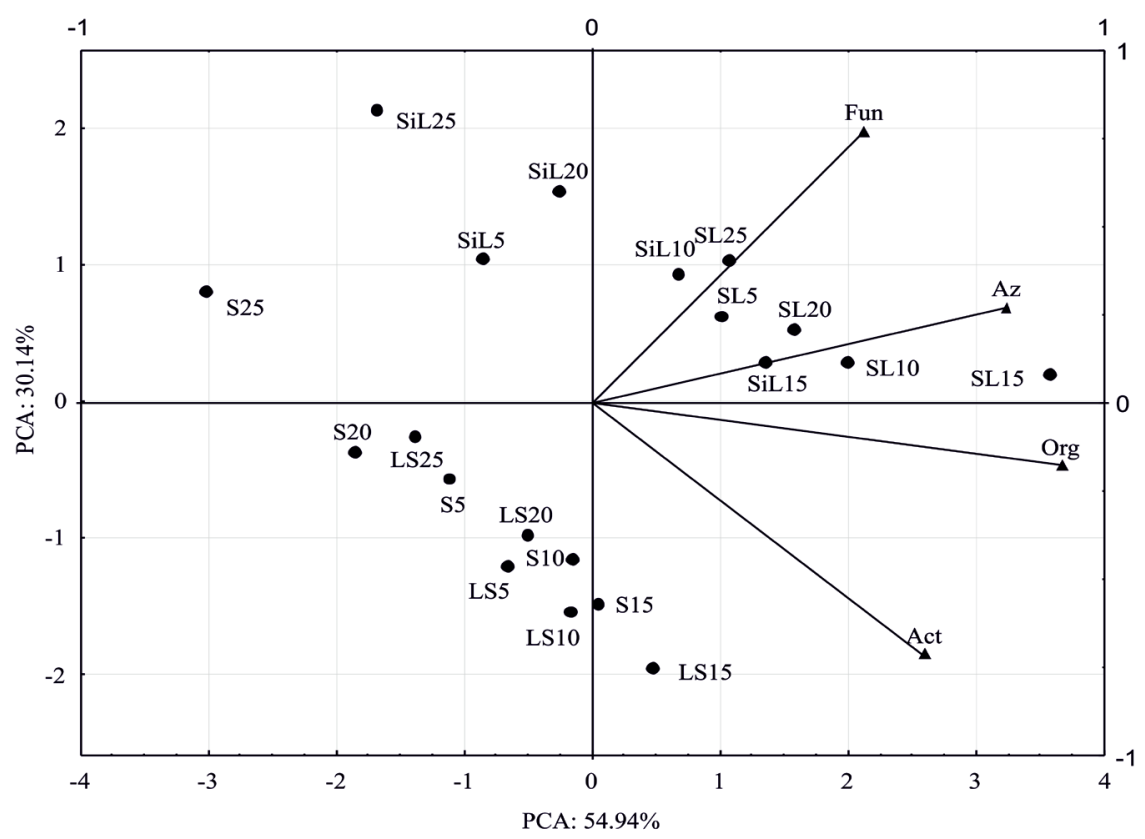

Fig. 1. Impact of temperature on the count of soil microorganisms. Org - heterotrophic bacteria, Az - Azotobacter, Act - actinomycetes, Fun - fungi; S - sand, LS - loamy sand, SL - sandy loam, SiL - silty loam; temperature: $5,10,15,20,25^{\circ} \mathrm{C}$.

T a b l e 3. Impact of temperature on the colony development and the ecophysiological diversity indexes of microorganisms

\begin{tabular}{|c|c|c|c|c|c|c|}
\hline \multirow{4}{*}{$\begin{array}{c}\text { Temperature } \\
\left({ }^{\circ} \mathrm{C}\right)\end{array}$} & \multicolumn{6}{|c|}{ Index } \\
\hline & \multicolumn{3}{|c|}{ Colony development } & \multicolumn{3}{|c|}{ Ecophysiological diversity } \\
\hline & \multicolumn{6}{|c|}{ Microorganisms } \\
\hline & Org & Act & Fun & Org & Act & Fun \\
\hline 5 & $34.48 \mathrm{c}$ & $23.97 d$ & $36.43 \mathrm{c}$ & $0.87 \mathrm{a}$ & $0.90 \mathrm{~b}$ & $0.73 \mathrm{c}$ \\
\hline 10 & $34.45 c$ & $25.37 \mathrm{~b}$ & $36.19 \mathrm{c}$ & $0.86 \mathrm{ab}$ & $0.90 \mathrm{~b}$ & $0.77 \mathrm{a}$ \\
\hline 15 & $34.55 \mathrm{c}$ & $26.12 \mathrm{a}$ & $39.70 \mathrm{a}$ & $0.87 \mathrm{a}$ & $0.92 \mathrm{a}$ & $0.77 \mathrm{a}$ \\
\hline 20 & $35.56 b$ & $24.54 \mathrm{c}$ & $37.42 b$ & $0.85 \mathrm{~b}$ & $0.90 \mathrm{~b}$ & $0.75 b$ \\
\hline \multirow[t]{3}{*}{25} & $36.25 \mathrm{a}$ & $25.05 \mathrm{bc}$ & $36.58 \mathrm{c}$ & $0.82 \mathrm{c}$ & $0.90 \mathrm{~b}$ & $0.71 d$ \\
\hline & \multicolumn{6}{|c|}{ Coefficient of correlation } \\
\hline & $0.90 *$ & -0.14 & $0.66^{*}$ & $-0.90 *$ & 0.23 & 0.41 \\
\hline
\end{tabular}

*Explanation as in Table 2 .

significantly. The highest counts of microorganisms were observed in sandy loam, lower in silty loam, and the lowest in sand. The most favourable temperature was $15^{\circ} \mathrm{C}$, and the least favourable temperatures were 25 and $5^{\circ} \mathrm{C}$, although in some soil formations, the temperature preferences were different. For example, the development of heterotrophic bacteria in sand, loamy sand, and silty loam were similar at 10 and $15^{\circ} \mathrm{C}$, while in sandy loam at $20^{\circ} \mathrm{C}$. A soil temperature of $25^{\circ} \mathrm{C}$ resulted in a reduction of actinomycete count in silty loam, sand, and loamy sand in comparison to $5^{\circ} \mathrm{C}$. The count of these microorganisms was similar only for sandy loam incubated at 5 and $25^{\circ} \mathrm{C}$. The highest counts of fungi were achieved during soil incuba- tion at the above-mentioned temperature of $15^{\circ} \mathrm{C}$. At this temperature, the count of fungi in sand, sandy loam, and silty loam was higher than at $5^{\circ} \mathrm{C}$.

The studied temperature range $\left(5-25^{\circ} \mathrm{C}\right)$ slightly changed the diversity of microorganisms (Table 3 ). The colony development index ranged: from 34.48 to 36.25 (incubation temperature 5 and $25^{\circ} \mathrm{C}$ ) for heterotrophic bacteria, from 23.97 to 26.12 (incubation temperature 5 and $15^{\circ} \mathrm{C}$ ) for actinomycetes, and from 36.43 to 39.70 (incubation temperature 5 and $15^{\circ} \mathrm{C}$ ) for fungi.

Soil temperature had an ambiguous effect on the value of the ecophysiological diversity index (EP). The highest EP values were found in fungi isolated from the soil at 
T a b l e 4. Impact of temperature on the activity of soil enzyme

\begin{tabular}{|c|c|c|c|c|c|c|c|}
\hline \multirow{3}{*}{$\begin{array}{c}\text { Temperature } \\
\left({ }^{\circ} \mathrm{C}\right)\end{array}$} & \multicolumn{7}{|c|}{ Enzymes } \\
\hline & Deh & Cat & Ure & $\beta$-glu & $\mathrm{Pac}$ & & Aryl \\
\hline & $\mu \mathrm{M} \mathrm{TFF}$ & $\mathrm{M} \mathrm{O}_{2}$ & ${\mathrm{mM} \mathrm{N}-\mathrm{NH}_{4}}$ & \multicolumn{4}{|c|}{$\mathrm{mM}$ PNP } \\
\hline & \multicolumn{7}{|c|}{$\mathrm{kg}^{-1}$ soil d.m. $\mathrm{h}^{-1}$} \\
\hline 5 & $10.98 b$ & $0.28 \mathrm{ab}$ & $1.30 \mathrm{e}$ & $0.52 \mathrm{c}$ & $1.08 \mathrm{~d}$ & $1.59 \mathrm{e}$ & $0.22 \mathrm{a}$ \\
\hline 10 & $11.47 \mathrm{a}$ & $0.29 b$ & $1.40 \mathrm{~d}$ & $0.40 \mathrm{~d}$ & $1.14 \mathrm{c}$ & $1.64 \mathrm{~d}$ & $0.23 \mathrm{a}$ \\
\hline 15 & $11.24 \mathrm{ab}$ & $0.31 \mathrm{a}$ & $1.52 \mathrm{c}$ & $0.58 b$ & $1.20 \mathrm{a}$ & $1.68 \mathrm{c}$ & $0.23 \mathrm{a}$ \\
\hline 20 & $9.83 \mathrm{c}$ & $0.27 \mathrm{c}$ & $1.67 \mathrm{~b}$ & $0.59 b$ & $1.17 \mathrm{~b}$ & $1.82 \mathrm{a}$ & $0.21 \mathrm{ab}$ \\
\hline \multirow[t]{3}{*}{25} & $9.15 \mathrm{~d}$ & $0.25 \mathrm{~d}$ & $1.78 \mathrm{a}$ & $0.61 \mathrm{a}$ & $1.14 \mathrm{c}$ & $1.79 \mathrm{~b}$ & $0.17 \mathrm{c}$ \\
\hline & \multicolumn{7}{|c|}{ Coefficient of correlation } \\
\hline & $-0.84 *$ & $-0.59 *$ & $0.99 *$ & $0.69 *$ & $0.56^{*}$ & $0.93 *$ & $-0.76^{*}$ \\
\hline
\end{tabular}

Deh - dehydrogenases, Cat - catalase, Ure - urease, Pac - acid phosphatase, Pal - alkaline phosphatase, Glu - $\beta$-glucosidase, Aryl arylsulfatase. Other explanation as in Table 2.

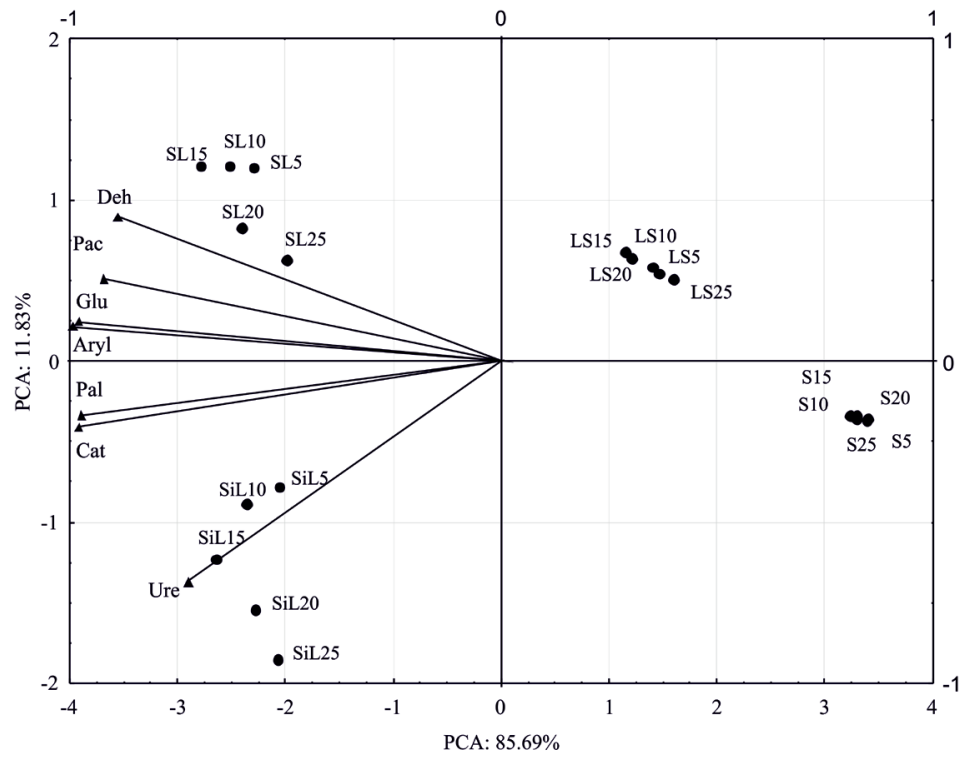

Fig. 2. Activity of soil enzymes in soils with different temperatures (PCA). Deh - the activity of dehydrogenases, Ure - urease, Pac - acid phosphatase, Pal - alkaline phosphatase, Glu - $\beta$-glucosidase, Aryl - arylsulfatase, Cat - catalase.S - sand, LS - loamy sand, $\mathrm{SL}$ - sandy loam, SiL - silty loam; temperature: $5,10,15,20,25^{\circ} \mathrm{C}$.

a temperature of $10^{\circ} \mathrm{C}$ and $15^{\circ} \mathrm{C}$ (Table 3). In turn, the EP of actinomycetes depended on the temperature within a very limited scope. The mean results obtained for all the soil formations indicate a certain trend of a favourable influence of $15^{\circ} \mathrm{C}$ on the ecophysiological diversity of these microorganisms. The EP index value of heterotrophic bacteria isolated from the soils incubated in the temperature range of $5-15^{\circ} \mathrm{C}$ was almost the same, while higher temperatures decreased the EP value by a few per cent.

In the presented study, soil incubation temperature also had a significant impact on the activity of soil enzymes (Table 4). The activity of urease and $\beta$-glucosidase was the highest in the soils incubated at $25^{\circ} \mathrm{C}$, but and that of alkaline phosphatase - at $20^{\circ} \mathrm{C}$, regardless of the type of soil formation. The activity of these enzymes was from $17 \%$ ( $\beta$-glucosidase) to $37 \%$ (urease) higher than at $5^{\circ} \mathrm{C}$. In turn, the activity of dehydrogenases was the highest in the soil samples at $10-15^{\circ} \mathrm{C}$, while the activity of catalase and acid phosphatase - at $15^{\circ} \mathrm{C}$, as in the case of the bacterial count.

Figure 2 shows the dispersion of enzymes in the system of the two first principal components. The horizontal axis explains $85.69 \%$ of the total variance of the variables, while the vertical axis $11.83 \%$. Vectors representing primary variables of all the studied enzymes focused around the axis representing the first variable principal component. They are characterized by a high negative fitting. The activity of all the enzymes had a highly significant positive correlation. However, no correlation between the activity 
of dehydrogenases and urease was found. The projection of cases on the plane with factors indicated that the highest enzyme activity was observed in sandy loam and silty loam, while the activity in loamy sand and sand was lower. Analysis of the distribution of individual cases representing enzymatic activity shows that the type of soil formation differentiated enzyme activity in a more significant way than the temperature.

\section{DISCUSSION}

Similarly to air temperature, soil temperature has a huge impact on the biology of the soil. According to Feng and Simpson (2009), the diversity of microorganisms changes in the soil within a temperature range from 2 to $20^{\circ} \mathrm{C}$. It is very important in the climate change context. Based on own research, it was demonstrated that microorganisms can adapt to low temperatures, which was confirmed by the fact that the optimal temperature for their development was $15^{\circ} \mathrm{C}$. At this point, it is worth mentioning that in Poland the average soil temperature ranges from 9 to $10^{\circ} \mathrm{C}$ (Michalska and Nidzgorska-Lencewicz, 2010). The 10-year study of Nieróbca (2005) shows that in a layer of $5 \mathrm{~cm}$ to $20 \mathrm{~cm}$, the average annual temperature of soil equals $9.4^{\circ} \mathrm{C}$, while the average value for the warmest months ie from June to September is only $16^{\circ} \mathrm{C}$. The latter is close to the average temperature, which has the most favourable effect on the proliferation of microorganisms in the present study.

A temperature decrease affects microorganisms in both ways: indirect and direct. The indirect action involves a reduction in the production capacity of plants and the resulting consequences for the microorganisms, while the direct action results from the adverse effect on the metabolism of microorganisms (Jefferies et al., 2010). Vorboyova et al. (1996) found that a long-term impact of low temperatures causes adaptation of microorganisms, which is reflected in the change of microbial metabolism and enzyme activity. Psychrophilic organisms are able to adapt to low temperatures (D'Amico et al., 2006), which enables their growth and development in various climatic zones.

The study of Jefferies et al. (2010) suggests that substrates released by plants and microbial cells in the autumn and winter can limit the growth of microorganisms, while an increase in temperature may increase the growth of psychrophilic microorganisms. As a result, a reduction in the bacterial biomass in late winter can be observed. This number of microbial cells results in activating nutrients necessary for plant growth in the early spring.

The soil temperature significantly influences the structure of microorganisms and their functionality. The conducted studies show that the highest colony development index (CD) of heterotrophic bacteria was recorded in soils incubated at $25^{\circ} \mathrm{C}$, while for actinomycetes and fungi it had its highest value at $15^{\circ} \mathrm{C}$. The soil temperature slightly changed the ecophysiological diversity of the studied groups of microorganisms. In turn, Papatheodorou et al. (2004) claim that bacterial diversity is greater in soils at higher temperatures. An increase in soil temperature may lead to changes in bacterial protein profiles, kinetic parameters related to breathing, and the decomposition rate of organic matter in the soil (Jezierska-Tys and Frąc 2008; Wyszkowska et al., 2013). Both own research and literature (Papatheodorou et al., 2004) indicate that bacterial diversity is limited by low temperatures.

The effect of temperature on enzyme activity is nota simple dependence. Biochemical activity, as well as microbial activity, is modified by the changing temperature of the soil (Jefferies et al., 2010; Papatheodorou et al., 2004; Vorboyova et al., 1996). Own research indicates that it is not possible to assume a constant temperature, because a stable temperature does not exist in the environment. Typically, the highest activity in the soil is recorded at $10-15^{\circ} \mathrm{C}$ for dehydrogenases, at $15^{\circ} \mathrm{C}$ for catalase and acid phosphatase, at $20^{\circ} \mathrm{C}$ for alkaline phosphatase, and at $25^{\circ} \mathrm{C}$ for urease and $\beta$-glucosidase. The optimum temperature for individual enzymes is a function of an increased reaction rate related to an increase in kinetic energy, and an increased rate of thermal denaturation of the enzyme above its critical $\left(60^{\circ} \mathrm{C}\right)$ temperature (Acosta-Marinez and Tabatabai, 2002). It has to be remembered that in the case of own research the soil incubation temperature was different (from 5 to $25^{\circ} \mathrm{C}$ ), which is significantly below the critical temperature. Therefore, in our research the thermal denaturation of enzymes did not accrue. Davidson and Janssens (2006) and Wallenstein et al. (2010) also observed variable activity of soil enzymes depending on the soil temperature. Enzyme activity increased during thaw and decreased with the onset of winter. The studies of these authors show that biochemical processes are much more intense under the conditions of variable temperature, which happens in the soil environment. A consequence of climate changes could be the limited availability of substrates to both intracellular and extracellular enzymes (Borowik et al., 2014; Davidson and Janssens, 2006; Kodaira, 2014; Singh et al., 2010). Acosta-Marinez and Tabatabai (2002) showed that arylamidase activity increased with a temperature increase from 20 to $60^{\circ} \mathrm{C}$. Higher temperature caused denaturation of this enzyme. According to D'Amico et al. (2006), psychrophiles produce cold-adapted enzymes that have high specific activities at low temperatures, significantly higher than those observed for their mesophilic counterparts.

In our research, the enzymatic activity was significantly positively correlated with the count of Azotobacter bacteria and fungi, for which the best proliferation conditions were in the soils at $15^{\circ} \mathrm{C}$. According to D'Amico et al. (2006), this results from the fact that the activity of psychrophilic microorganisms is often an order of magnitude higher in comparison to that of mesophiles.

According to Michalska and Nidzgorska-Lencewicz (2010), the average annual temperature of the soil is approx. $9-10^{\circ} \mathrm{C}$. Thus, the adaptation of microorganisms to this temperature was the most possible. The number of microorganisms was positively correlated with the richness of soil with nutrients and the content of organic carbon (Davidson 
and Janssens, 2006; Jefferies et al., 2010). In our research, organic carbon, total nitrogen, and bioavailable phosphorus, potassium, calcium, and magnesium content probably determined the positive correlation between the activity of soil dehydrogenases, catalase, urease, acid phosphatase, alkaline phosphatase, $\beta$-glucosidase, and arylsulfatase and the content of colloidal clay and silt fractions.

\section{CONCLUSIONS}

1. The most favourable temperature for the development of soil heterotrophic bacteria, Azotobacter, fungi, and actinomycetes was $15^{\circ} \mathrm{C}$. Typically, in the soil, the highest activity of dehydrogenases was observed at $10-15^{\circ} \mathrm{C}$, catalase and acid phosphatase at $15^{\circ} \mathrm{C}$, alkaline phosphatase at $20^{\circ} \mathrm{C}$, and urease and $\beta$-glucosidase at $25^{\circ} \mathrm{C}$.

2. The highest colony development index for heterotrophic bacteria was observed in the soils incubated at $25^{\circ} \mathrm{C}$, while for actinomycetes and fungi at $15^{\circ} \mathrm{C}$. The incubation temperature of the soil only slightly changed the ecophysiological diversity of the studied groups of microorganisms.

3. The response of soil microorganisms and enzymes was more dependent on the granulometric composition, organic carbon, and total nitrogen of the soil than on its temperature.

4. The observed climate changes might have a limited impact on the soil microbiological activity, because of the high ability of microorganisms to adopt.

\section{REFERENCES}

Acosta-Marinez V. and Tabatabai M.A., 2002. Inhibition of arylamidase activity in soils by toluene. Soil Biol. Biochem., 34, 229-237.

Adak T. and Chakravarty N.V.K., 2013. Relation between soil temperature and biophysical parameters in Indian mustard seeds. Int. Agrophys., 27, 359-367.

Alef K., Nannipieri P., and Trazar-Cepeda C., 1998. Methods in Applied Soil Microbiology and Biochemistry (Eds K. Alef, P. Nannipieri). Academic Press, Harcourt Brace Company, London, UK.

Borowik A., Wyszkowska J., Kucharski J., Baćmaga M., Boros-Lajszner E., and Tomkiel M., 2014. Sensitivity of soil enzymes to excessive zinc concentrations. J. Elem., 19(3), 637-648.

Carter M.R., 1993. Soil Sampling and Methods of Analysis. Canadian Society of Soil Science, Lewis Publishers, London, UK.

D’Amico S., Collins T., Marx J.C., Feller G., and Gerday C., 2006. Psychrophilic microorganisms: challenges for life. EMBO, 7(4), 385-389.

Davidson E.A. and Janssens I.A., 2006. Temperature sensitivity of soil carbon decomposition and feedbacks to climate change. Nature, 440, 165-173.

De Leij F.A.A.M., Whipps J.M., and Lynch J.M., 1993. The use of colony development for the characterization of bacterial communities in soil and on roots. Microb. Ecol., 27, 81-97.
Feng X. and Simpson M.J., 2009. Temperature and substrate controls on microbial phospholipid fatty acid composition during incubation of grassland soils contrasting in organic matter quality. Soil Biol. Biochem., 41, 804-812.

Jastrzębska E. and Kucharski J., 2007. Dehydrogenases, urease and phosphatases activities of soil contaminated with fungicides. Plant Soil Environ., 53, (2), 51-57.

Järvan M., Edesi L., Adamson A., and Võsa T., 2014. Soil microbial communities and dehydrogenase activity depending on farming systems. Plant Soil Environ., 60(10), 459-463.

Jefferies R.L., Walker N.A., Edwards K.A., and Dainty J., 2010. Is the decline of soil microbial biomass in late winter coupled to changes in the physical state of cold soils? Soil Biol. Biochem., 42, 129-135.

Jezierska-Tys S. and Frąc M., 2008. Microbiological indices of soil quality fertilized with dairy sewage sludge. Int. Agrophysics, 22, 215-219.

Kodaira H., 2014. Responding to climate change and expectations for research. Paddy Water Environ., 12(2), 211-212.

Kucharski J. and Wyszkowska J., 2004. Inter-relationship between number of microorganisms and spring barley yield and degree of soil contamination with copper. Plant Soil Environ., 50(6), 243-249.

Licznar P. and Rojek M., 2004. Soil profile thermal conditions evaluation by means of artificial neural networks (in Polish). Acta Agrophysica, 3(2), 317-323.

Michalska B. and Nidzgorska-Lencewicz J., 2010. Daily variability of temperature in the profile of overgrown soil in the Ostoja meteorological station (in Polish). Folia Pomer. Uni. Technol. Stetin., Agric., Aliment., Pisc., Zootech., 279(15), 63-72.

Nelson D.W. and Sommers L.E., 1996. Total carbon, organic carbon, and organic matter. In: Method of Soil Analysis: Chemical Methods (Ed. D.L. Sparks). American Society of Agronomy, Madison, WI, USA.

Nieróbca A., 2005. Comparison of soil temperature in bare fallow and in soil under lawn (in Polish). Acta Agrophys., 6(2), 443-453.

Öhlinger R., 1996. Dehydrogenase activity with the Substrate TTC. In: Methods in soil biology (Eds F. Schinner, R. Ohlinger, E. Kandler, R. Margesin). Springer Verlag, Berlin, Germany.

Papatheodorou E.M., Argyropoulou M.D., and Stamou G.P., 2004. The effects of large- and small-scale differences in soil temperature and moisture on bacterial functional diversity and the community of bacterivorous nematodes. Appl. Soil Ecol., 25, 37-49.

Sarathchandra S.U., Burch G., and Cox N.R., 1997. Growth patterns of bacterial communities in the rhizoplane and rhizosphere of with clover (Trifolium repens L.) and perennial ryegrass (Lolium perenne L.) in long-term pasture. Appl. Soil Ecol., 6, 293-299.

Singh B.K., Bardgett R.D., Smith P., and Reay D.S., 2010. Microorganisms and climate change: terrestrial feedbacks and mitigation options. Nat. Rev. Microbiol., 8, 779-790.

Statsoft, Inc., Statistica, 2012. Data analysis software system, version 10.0., http://www.statsoft.com 
Tortora G.J., Funke B.R., and Case C., 2004. Microbiology an introduction. Pearson Education. Inc. Benjamin Cummings. San Francisco, USA.

Vorboyova E.A., Soina V.S., and Mulukin A.L., 1996. Microorganisms and enzyme activity in permafrost after removal of long-term cold stress. Adv. Space Res., 18(12), 103-108.

Wallenstein M., Allison S.D., Ernakovich J., Steinweg J.M., and Sinsabaugh R., 2010. Controls on the temperature sensitivity of soil enzymes: A key driver of in situ enzyme activity rates. Soil Biol., 22, 245-258.
Wyszkowska J., Borowik A., Kucharski J., Baćmaga M., Tomkiel M., and Boros-Lajszner E., 2013. The effect of organic fertilizers on the biochemical properties of soil contaminated with zinc. Plant Soil Environ., 59(11), 500-504.

Zeppel M.J.B., Lewis D.L., Chaszar B., Smith R.A., Medlyn B.E., Huxman T.E., and Tissue D.T., 2012. Nocturnal stomatal conductance responses to rising $\left[\mathrm{CO}_{2}\right]$, temperature and drought. New Phytologist., 193(4), 929-938. 